\title{
Performance of fatty acid composition, iodine value, carotene content, height and height increment of oil palm interspecific hybrids
}

\author{
${ }^{1}$ Alyasa, J., ${ }^{1, *}$ Shamsiah, A. and ${ }^{2}$ Mohd Din, A. \\ ${ }^{I}$ Faculty of Plantation and Agrotechnology, Universiti Teknologi MARA Cawangan Melaka, Kampus Jasin, \\ 77300 Merlimau, Melaka. \\ ${ }^{2}$ Breeding and Tissue Culture Unit, Malaysian Palm Oil Board, 43000 Kajang, Selangor, Malaysia
}

\begin{abstract}
Article history:
Received: 16 April 2021

Received in revised form: 19

July 2021

Accepted: 15 November 2021

Available Online: 26

November 2021

Keywords:

Carotene,

Fatty acids,

Height increment,

Oil palm interspecific hybrids
\end{abstract}

DOI:

https://doi.org/10.26656/fr.2017.5(S4).008

\begin{abstract}
A total of sixteen oil palm interspecific hybrid progenies were evaluated for their fatty acid composition, iodine value, carotene content, height and height increment at Malaysian Palm Oil Board (MPOB) Bagan Datuk, Malaysia. Based on the results, unsaturated fatty acids were higher with a range of $60 \%$ compared to current breeding materials. Iodine value showed a considerable amount of the oil palm interspecific hybrid which was around 65. Carotene among some individuals showed an outstanding value of $3424 \mathrm{ppm}$. Height and height increment showed lower value than current breeding materials with an average $0.17 \mathrm{~m}$ height increment per year. Heritability values showed that the genetic component gave higher influence towards height and height increment while the fatty acid composition and carotene content were largely influenced by the environment.
\end{abstract}

\section{Introduction}

The oil palm in Malaysia begins with the dura as planting materials which originated from Bogor Botanical Garden, Indonesia (Yee and Chandran, 2005). It first came to Malaysia as ornamental palms, before it was being used as a commodities crop. With the knowledge of monogenic inheritance of the fruit shell, dura has been replaced with tenera which involved the cross between the dura and the pisifera (Beirnaert and Vanderweyen, 1941). Tenera produces more oil from its thick mesocarp thus could achieve more oil yield. The oil palm breeders seem to have a narrow genetic base as the oil palm is originated from four palms that were planted in Indonesia and the descendants brought to Malaysia. This situation has caused them to broaden the genetic base of the oil palm by going for germplasm collection expedition and to bring back the oil palm germplasm to Malaysia.

The expedition to collect the oil palm germplasm in the oil palm centres of origin, for Elaeis guineensis had been done by collecting them in several African countries such as Angola, Nigeria, Senegal etc (Rajanaidu et al., 2013). For Elaeis oleifera, most of the countries are from Central and South America such as Colombia, Brazil, Panama etc. During the prospection, the bunch of samples were processed in situ before being brought back. The oil palm germplasm then was mostly planted in MPOB Oil Palm Genebank in Kluang, Johor and was used according to several steps by MPOB which were germplasm, evaluation, utilization and conservation. The evaluation of the oil palm germplasm was later being used as part of commercial oil palm planting materials such as from Nigeria which tremendously being used as the maternal source. This was being proved by looking into the released PS1 series planted by several private plantations and smallholders.

The cross between Elaeis guineensis and Elaeis oleifera could produce oil palm interspecific hybrids as they are sexually compatible. In Malaysia, two important traits have been identified by the oil palm researchers in the oil palm interspecific hybrid. Firstly it offers slow growth with short trunks. The short trunk has given eagerness to oil palm breeders as it makes easy jobs for the harvester. Secondly are the oil quality traits such as higher unsaturated fatty acids and above normal iodine value. In other countries, they found the third advantage of the oil palm interspecific hybrid which is resistant to oil palm diseases. In South American countries, diseases such as bud rot and lethal decay have devastated many infected areas which cost millions of dollars. In Columbia, they cost up to 50 million US dollars in losses to the planters from the diseases (Benítez and García, 2014). To react to the situation, they started to replace 
the current planting materials on their oil palm plantations with oil palm interspecific hybrids. For some planers, this is the only way to overcome the situation while some of them are planted with Elaeis oleifera. In Malaysia, the oil palm interspecific hybrid is mostly pursued research. Aside from fatty acids and iodine value, carotene is one of the traits that are being evaluated by oil palm breeders and higher carotene mean the oil quality is considered good.

The oil palm interspecific hybrid produced by crossing between Elaeis guineensis with Elaeis oleifera or vice versa. Based on previous studies, the oil palm interspecific hybrid had three obvious advantages, namely, shorter trunk, good oil quality and resistance to disease (Barba et al., 2015; Astorkia et al., 2019). Since the bud rot disease is not critical in Malaysia, oil palm breeders focused on shorter trunk and the oil quality characters. This paper deliberates results on the evaluation of fatty acid composition, carotene content, height and height increment of the oil palm interspecific hybrids. Findings in this study may be useful for future oil palm breeding programs.

\section{Materials and methods}

\subsection{Materials}

The sixteen oil palm interspecific hybrid progenies comprising $\mathrm{T}$ (E. guineensis var. tenera) $\times \mathrm{O}$ (Elaeis oleifera) and the reciprocal, $\mathrm{O} \times \mathrm{T}$ are used in this study (Table 1). The palms were planted in shallow peat soil with an average of $90.88 \mathrm{~mm}$ of rainfall during the 9 months bunch harvesting period, during the study. The trial was planted in Trial 0.208 at MPOB Bagan Datuk, Perak, Malaysia in 1988 and statistically laid out in

Table 1. Oil palm interspecific hybrid progenies in Trial 0.208, MPOB Bagan Datuk, Perak.

\begin{tabular}{|c|c|c|c|c|}
\hline Progeny code & Cross type & $\begin{array}{c}\text { Replication } \\
1\end{array}$ & $\begin{array}{c}\text { Replication } \\
2\end{array}$ & Total \\
\hline MS3402 & $\mathrm{T} \times \mathrm{O}$ & 5 & 5 & 10 \\
\hline MS3406 & $\mathrm{O} \times \mathrm{T}$ & 5 & 5 & 10 \\
\hline MS3407 & $\mathrm{O} \times \mathrm{T}$ & 5 & 5 & 10 \\
\hline MS3410 & $\mathrm{O} \times \mathrm{T}$ & 5 & 5 & 10 \\
\hline MS3421 & $\mathrm{O} \times \mathrm{T}$ & 5 & 5 & 10 \\
\hline MS3424 & $\mathrm{O} \times \mathrm{T}$ & 5 & 5 & 10 \\
\hline MS3444 & $\mathrm{O} \times \mathrm{T}$ & 5 & 5 & 10 \\
\hline MS3445 & $\mathrm{O} \times \mathrm{T}$ & 5 & 5 & 10 \\
\hline MS3449 & $\mathrm{O} \times \mathrm{T}$ & 5 & 5 & 10 \\
\hline MS3451 & $\mathrm{T} \times \mathrm{O}$ & 5 & 5 & 10 \\
\hline MS3452 & $\mathrm{T} \times \mathrm{O}$ & 5 & 5 & 10 \\
\hline MS3453 & $\mathrm{T} \times \mathrm{O}$ & 5 & 5 & 10 \\
\hline MS3464 & $\mathrm{T} \times \mathrm{O}$ & 5 & 5 & 10 \\
\hline MS3478 & $\mathrm{O} \times \mathrm{T}$ & 5 & 5 & 10 \\
\hline MS3479 & $\mathrm{T} \times \mathrm{O}$ & 5 & 5 & 10 \\
\hline MS3492 & $\mathrm{T} \times \mathrm{O}$ & 5 & 5 & 10 \\
\hline
\end{tabular}

eISSN: $2550-2166$
Randomized Complete Block Design (RCBD) with two replications. The planting distance was $8.8 \mathrm{~m}$ apart in a triangular pattern. A total of 10 palms were selected from each of progeny at five palms per replication. Only one bunch per palm was harvested and evaluated for this study making up a total of 160 bunches as shown in Table 1.

\subsection{Sample collection and preparation}

Ripe fresh fruit bunches were harvested using a chisel attached to a pole. The harvested bunches were chopped into three separate portions and three to four spikelets were selected from each portion. The selection of spikelets was done at random to represent a balanced composition of the fruit set. The oil from fruits was extracted by means of the solvent extraction method. The spikelets were softened by autoclaving and later fruit was minced into small pieces manually before drying up in the oven for 3 hours. The dried mesocarp was ground by using a blender and kept into a desiccator. The dried mesocarp was mixed with hexane and later separated by using rotary evaporator apparatus.

\subsection{Oil analysis}

Oil collected was converted into fatty acid methyl ester (FAME) before being placed into mini vials. The fatty acid components were determined by chromatography technique by using gas chromatography of brand Agilent 5973N. Vials were sorted into the rack sampler and the injection process automatically began later. The temperature of the column in the gas chromatography was set and maintained to $180^{\circ} \mathrm{C}$ where helium gas was used as a carrier gas, which flowed at a rate of $40 \mathrm{~mL} / \mathrm{min}$. Meanwhile, the temperature of the detector and injection was set at $220^{\circ} \mathrm{C}$. Data output was in form of raw which intended fatty acids were selected and calculated.

Iodine value was determined based on calculation introduced by the American Oil Chemist Society (AOCS), that related to the composition of unsaturated fatty acids as reported by Kyriakidis and Katsiloulis (2000). The unsaturated fatty acid components were gathered from data output based on gas chromatography. Carotene content was determined by using a spectrophotometer with an absorbance of $446 \mathrm{~nm}$. Before the sample is run in the spectrophotometer, the oil must be converted into FAME by titration process. The oil sample was diluted by using isooctane. The colour of the oil samples was brighter than it's followed Beer's Law.

The height of the palms was measured by means of a measuring tape attached to an adjustable pole. The measurement was done from the ground to the frond 
number 41. The height increment was calculated based on the calculation of (Breure and Powell, 1988).

Height increment $=$ Height at year $t / t-2$, where $t$ is number of years,

Data were calculated and analysed by using analysis of variance (ANOVA) by using SAS 9.1 version. Progeny means and overall means were compared by Least Significance Different (LSD) at a 5\% level of probability. Broad sense heritability was calculated based on ANOVA components.

\section{Results and discussion}

Mean squares (Table 2) showed most of the oil traits were not significantly different as compared to height and height increment, which were highly significant.

Palmitic acid, which is a saturated fatty acid had a mean of $34.71 \%$ of the total 160 bunch sample with a value of individual palm ranging between $23.36 \%$ to $45.36 \%$ (Table 3 ) and range of progeny mean $32.46 \%$ to $37.02 \%$ and mostly distributed between $33 \%$ to $37 \%$ (Figure 1). Progeny MS3452 had scored the lowest palmitic acid with $32.46 \%$ which was favourable by oil palm breeders. In comparison, Choo et al. (1997) found high variation in palmitic acid and within the range of this study. It ranges from $32.2 \%$ to $35.4 \%$ which indicated that the progenies used in this study were more variable than those used by Choo et al. (1997). Another study by Noh et al. (2012) found the palmitic acid of oil palm interspecific hybrid (backcross) ranging between $34.22 \%$ to $38 \%$ with a mean of $35.07 \%$ and Chaves et al. (2018) stated that 3 progenies of the oil palm interspecific hybrid had delivered a range of palmitic acid between $26.3 \%$ to $32.5 \%$. Studies by Yap et al. (1991) had reported with mean of $32.4 \%$ and $35.6 \%$ from two progenies which gave the result of this study as an intermediate value. The lower value of the palmitic acid normally is more favourable to oil palm breeders since the price of palm oil increases with lower percentage of stearin. The palmitic acid is one of the components of stearin as lower stearin will increase the olein and this will be reflected in the price.

Stearic acid which is normally the second most abundant saturated fatty acid in palm oil gave a mean of $2.85 \%$ with individual palms ranging from $1.79 \%$ to $4.81 \%$ (Table 3 ). The range of progeny mean was $2.36 \%$ to $3.31 \%$ and mostly distributed between $2.4 \%$ to $3 \%$ (Figure 1). The highest value of the stearic acid was at $3.31 \%$ (Progeny MS3444) while the lowest was at 2.36\% (Progeny MS3421). Choo et al. (1997) found that the stearic acid ranged from $3.2 \%$ to $4.1 \%$ within the oil palm interspecific hybrid. The materials used in this study seemed to be more diverse than Choo et al. (1997) results. Diversified values will give more possibilities to select for further breeding and improvement program. Noh et al. (2012) reported a range from $4.03 \%$ to $6.95 \%$ for stearic acid among the oil palm interspecific hybrid. The mean in this study was lower than reported by Yap et al. (1991), which recorded $3.1 \%$ and $4.4 \%$ for two progenies. As a saturated fatty acid, lower stearic is of interest for better palm oil quality but for confectionery applications, high stearic could be considered as a fat substitute. The study by Mancini et al. (2015) found the value of stearic acid was higher than this study at $4.5 \%$ and placed behind palmitic acid in the Elaeis guineensis sample. Montoya et al. (2014) also stated the same situation where the stearic acid had a range between $3.7 \%$ to $8.4 \%$ of the Elaeis guineensis.

Myristic acid which was among the lowest saturated fatty acid in this study had a mean value of $0.49 \%$ with individual palms ranging between $0.21 \%$ and $1.3 \%$ (Table 3), the progeny mean ranges from $0.40 \%$ to $0.56 \%$ and mostly distributed around $0.4 \%$ to $0.5 \%$ (Figure 1). Progeny MS3424 had the highest value at $0.56 \%$ while Progeny MS3445 gave $0.4 \%$. Choo et al. (1997) reported the range of the myristic from $0.5 \%$ to $1.6 \%$ whereas Noh et al. (2012) reported a range from $0.48 \%$ to $0.86 \%$. Progenies in this study however were less variable for myristic acid. Yap et al. (1991) reported a value of $0.4 \%$ for two progenies evaluated, which was a bit lower than this study.

Oleic acid is the fatty acid with the highest value in this study, with a mean of $48.11 \%$ and individual palms ranging from $36.65 \%$ to $57.47 \%$ (Table 3 ). The progeny mean ranges from $45.61 \%$ to $49.96 \%$ and is mostly distributed between $48 \%$ and $49.96 \%$ (Figure 1). Progeny MS3452 had the highest value with $49.96 \%$

Table 2. Mean squares of fatty acid composition, iodine value, carotene, height and height increment

\begin{tabular}{cccccccccccc}
\hline Source & df & Myristic & Palmitic & Stearic & Oleic & Linoleic & Linolenic & $\begin{array}{c}\text { Iodine } \\
\text { Value }\end{array}$ & Carotene & Height & $\begin{array}{c}\text { Height } \\
\text { Increment }\end{array}$ \\
\hline Rep (R) & 1 & $0.0008^{\text {ns }}$ & $23.41^{\text {ns }}$ & $0.98^{\text {ns }}$ & $22.31^{\text {ns }}$ & $0.32^{\text {ns }}$ & $0.06^{\text {ns }}$ & $36.15^{\text {ns }}$ & $2264182^{\text {ns }}$ & $14.61^{* *}$ & $0.01^{* *}$ \\
Progenies (P) & 15 & $0.031^{\text {ns }}$ & $22.82^{\text {ns }}$ & $0.85^{* *}$ & $20.41^{\text {ns }}$ & $2.93^{\text {ns }}$ & $0.11^{\text {ns }}$ & $34.18^{*}$ & $603377^{\text {ns }}$ & $10.58^{* *}$ & $0.01^{* *}$ \\
RxP & 15 & $0.033^{\text {ns }}$ & $1.96^{\text {ns }}$ & $0.37^{\text {ns }}$ & $8.06^{\text {ns }}$ & $2.03^{\text {ns }}$ & $0.10^{\text {ns }}$ & $4.32^{\text {ns }}$ & $791737^{\text {ns }}$ & $0.92^{\text {ns }}$ & $0.0009^{\text {ns }}$ \\
Within palms & 128 & 0.025 & 11.19 & 0.27 & 13.66 & 3.15 & 0.07 & 15.02 & 635614 & 0.57 & 0.0005 \\
\hline
\end{tabular}

Values are mean squares of the fatty acid composition, iodine value, carotene, height and height increment.

${ }^{*}, * *$, ns significant at $\mathrm{P}<0.05$, significant at $\mathrm{P}<0.01$, not significant respectively 
Table 3. Statistic of overall mean for fatty acid components

\begin{tabular}{ccccccc}
\hline Traits & Mean & Std Dev & Std Error & Minimum & Maximum & Progeny Range (Mean) \\
\hline Myristic (\%) & 0.49 & 0.16 & 0.01 & 0.21 & 1.30 & $0.40-0.56$ \\
Palmitic (\%) & 34.71 & 3.39 & 0.26 & 23.36 & 45.36 & $32.46-37.02$ \\
Stearic (\%) & 2.85 & 0.58 & 0.04 & 1.79 & 4.81 & $2.36-3.31$ \\
Oleic (\%) & 48.11 & 3.71 & 0.29 & 36.65 & 57.47 & $45.61-49.96$ \\
Linoleic (\%) & 12.82 & 1.73 & 0.13 & 0.00 & 16.65 & $11.41-13.40$ \\
Linolenic (\%) & 0.26 & 0.29 & 0.02 & 0.00 & 0.91 & $0.08-0.45$ \\
Iodine Value & 64.53 & 3.90 & 0.31 & 43.28 & 73.76 & $61.86-67.36$ \\
Carotene (ppm) & 1243.00 & 64.10 & 810.90 & 89.56 & 3424.00 & $740.8-1570.4$ \\
Height (m) & 5.65 & 1.28 & 0.10 & 3.40 & 9.51 & $4.53-7.49$ \\
Height Increment (m) & 0.17 & 0.03 & 0.01 & 0.10 & 0.29 & $0.13-0.22$ \\
\hline
\end{tabular}

Value of mean, minimum and maximum of fatty acid is in percentage and carotene in ppm

whereas Progeny MS3444 had the lowest at $45.61 \%$. Choo et al. (1997) reported a mean of the oleic acid ranging from $34.4 \%$ to $51.8 \%$ whereas Noh et al. (2002) reported a mean of $41.18 \%$ to $47.03 \%$. In comparison to Choo et al. (1997) results, the oleic acid values were more variable than materials used in this study. Yap et al. (1991) reported that the value of the oleic acid was $44.8 \%$ and $52.4 \%$ for two progenies. However, some individual palms showed a higher percentage of oleic acid up to $57.47 \%$. The higher oleic acid is reflected in the higher price of palm oil as higher olein increases the oil quality.

Linoleic acid which is a polyunsaturated fatty acid gave a mean of $12.82 \%$ with individual palms ranging from $0 \%$ to $16.65 \%$ (Table 3 ). The progeny mean ranged from $11.41 \%$ to $13.40 \%$ and was mostly distributed between $12 \%$ and $13.4 \%$ (Figure 1). Progeny MS3445 gave the highest value at $13.40 \%$ whereas Progeny MS3402 gave the lowest at $11.41 \%$. Choo et al. (1997) reported a range of linoleic acid from $10.8 \%$ to $16.5 \%$ whereas Noh (2012) reported a range from $11.04 \%$ to $16.48 \%$ among oil palm interspecific hybrids. In comparison to Yap et al. (1991), the linoleic acid in this study was higher compared to the single progeny they evaluated. As part of the unsaturated fatty acid, higher linoleic acid is considered favourable for oil quality.

Linolenic acid had mean of $0.26 \%$ with individual palms ranging from $0 \%$ to $0.91 \%$ (Table 3) Progeny mean ranged from $0.08 \%$ to $0.45 \%$ and mostly distributed between $0.1 \%$ and $0.4 \%$ (Figure 1). Progeny MS3451 had the highest value at $0.45 \%$ whereas Progeny MS3479 had the lowest at $0.08 \%$. Choo et al. (1997) reported a range of around $0.5 \%$ for oil palm interspecific hybrids. In comparison, this value was higher than the materials used in this study. Yap et al. (1991) reported values of $0.4 \%$ and $0.6 \%$ for two evaluated progenies.

Iodine value (IV) had a mean of 64.52 with individual palm ranging from 43.28 to 73.76 (Table 3) range of progeny mean 61.86 to $67.36 \%$ and mostly distributed between 63 to 66 (Figure 1). Progeny MS3452 had the highest value at 67.36 whereas Progeny MS3492 was lowest at 61.89. Noh et al. (2012) reported a range of around 57.6 to 66.54 of iodine value. In comparison, materials used in this study were less variable but the individual performance was acceptable which a value up to 73.76. Higher content of iodine is a reflection of higher unsaturation fatty acid and this has been sought by oil palm breeders.

Carotene content in this study had a mean of 1243.34 ppm with individual palm ranging between $89.55 \mathrm{ppm}$ to $3424.25 \mathrm{ppm}$ (Table 3) range of progeny mean 740.8 ppm to $1570.4 \mathrm{ppm}$ and mostly distributed between 1000 ppm to 1570.4 ppm (Figure 1). Progeny MS3478 had the highest with 1570.5 whereas Progeny MS3444 had the lowest at 740.8. Choo et al. (1997) reported a range of around $1250 \mathrm{ppm}$ to 1450 of one of the progenies which compared to materials used in this study had variable carotene content. In comparison to Noh et al. (2012), the individual performance in this study was far ahead with the highest value up to $3424.25 \mathrm{ppm}$ compared with $1989.4 \mathrm{ppm}$.

Height had an overall mean of $5.65 \mathrm{~m}$ while height increment at $0.17 \mathrm{~m}$ (Table 3). Height had recorded of individual height ranging from $3.40 \mathrm{~m}$ to $9.51 \mathrm{~m}$ while height increment ranging between $0.10 \mathrm{~m}$ to $0.29 \mathrm{~m}$. Progeny MS3453 had recorded the highest value of height with $7.5 \mathrm{~m}$ while progeny MS3407 had the lowest at $4.54 \mathrm{~m}$. Progeny MS3453 had recorded the highest value of height increment of $0.23 \mathrm{~m}$ while progeny MS3407 and MS3444 had scored lowest at $0.13 \mathrm{~m}$. In comparison, Sunilkumar et al. (2015) found that the height increment of the oil palm interspecific hybrid range of around $0.41 \mathrm{~m}$ to $0.46 \mathrm{~m}$. Noh et al. (2012) found that the oil palm interspecific hybrid backcross a bit lower range of around $0.34 \mathrm{~m}$ to $0.38 \mathrm{~m}$. This clearly showed that the material used in this study had a lower height increment. Shorter palm is an advantage to the oil 

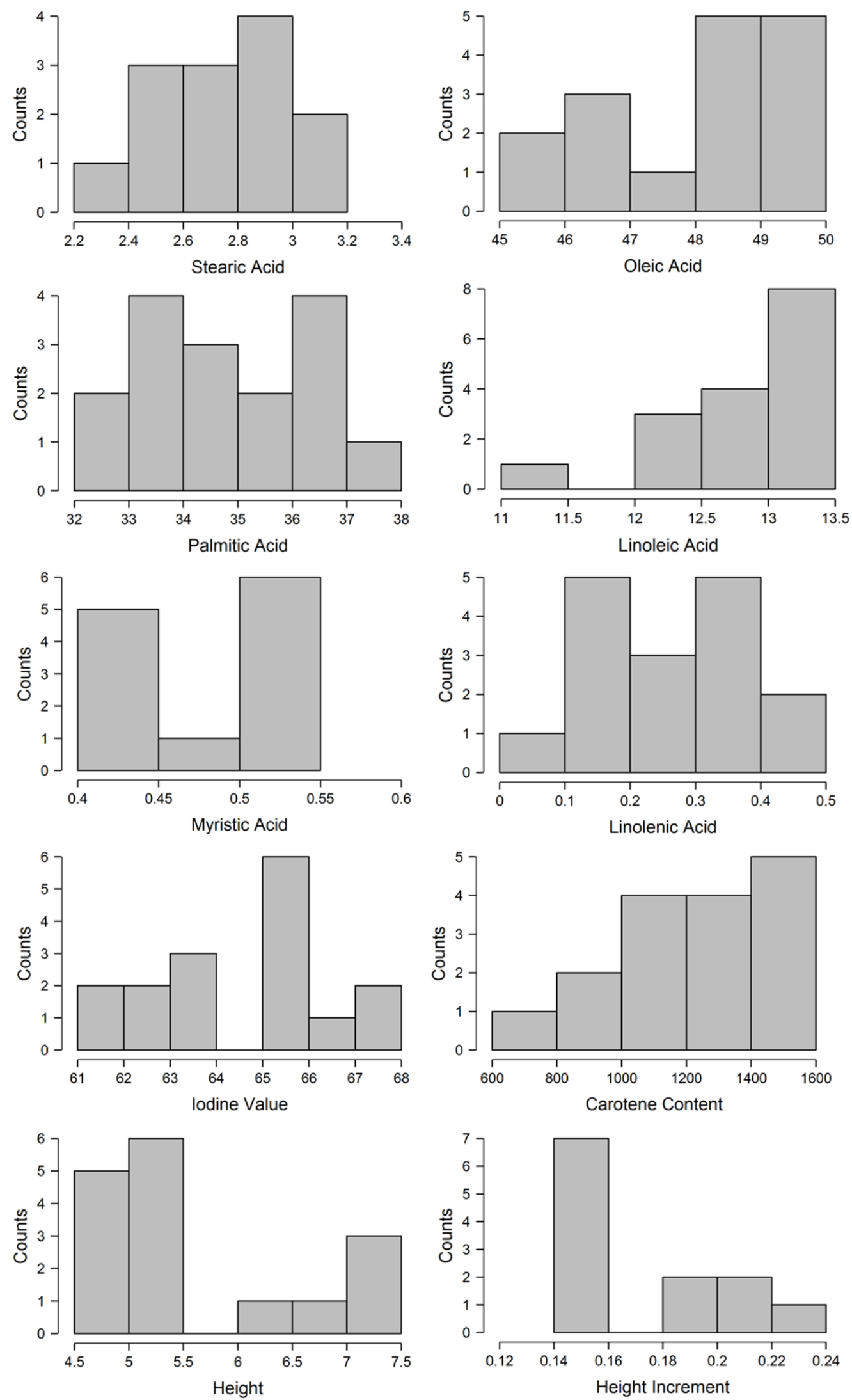

Figure 1. Frequency distribution of fatty acids compositions, iodine value, carotene content, height and height increment.

palm industry which resulted in a lower cost of harvesting (Yaakub et al. 2020). According to Barcelos et al. (2015) as palms age, oil palm trees are taller than two-three meters cutting bunch stalk becomes physically challenging, bunch fall bruises fruits resulting lower oil quality and difficult to assess the bunch ripeness.

\subsection{Heritability}

The heritability value of all evaluated traits was considered low to moderate based on broad sense heritability with two traits giving a value of zero while two traits having more than $40 \%$ (Table 4 ). This means that the evaluated traits had strong environmental effects on the expression of the phenotypic traits. Lower 
Table 4. Phenotypic Coefficients Variance (PCV), Genotypic Coefficients Variance (GCV) and Broad Sense Heritability $\left(\mathrm{h}^{2}{ }_{\mathrm{B}}\right)$ for fatty acid compositions, iodine value, carotene content, height and height increment.

\begin{tabular}{lcccc}
\hline Traits & PCV $(\%)$ & GCV $(\%)$ & GCV $/ \mathrm{PCV}(\%)$ & $\mathrm{h}^{2}{ }_{\mathrm{B}}=2 \mathrm{t}_{\mathrm{g}}$ \\
\hline Myristic & 33.30 & 0.00 & 0.00 & 0.00 \\
Palmitic & 10.50 & 4.16 & 39.62 & 31.34 \\
Stearic & 20.52 & 7.67 & 37.38 & 24.24 \\
Oleic & 8.02 & 2.31 & 28.80 & 16.52 \\
Linoleic & 14.05 & 2.33 & 16.58 & 4.95 \\
Linolenic & 110.74 & 9.82 & 8.87 & 1.56 \\
IV & 6.57 & 2.67 & 40.64 & 33.10 \\
Carotene & 65.67 & 0.00 & 0.00 & 0.00 \\
Height & 18.81 & 12.30 & 0.65 & 43.24 \\
Height Increment & 22.34 & 17.23 & 0.77 & 57.55 \\
\hline
\end{tabular}

Negative estimate and reasonable value is zero

heritability value means that the traits are less heritable and much affected by the environmental factor and vice versa. Rafii et al. (2001) found that low levels of GCV will further make low levels of the heritability estimation of most evaluated traits except for one. Furthermore, Rafii et al. (2002) mentioned that the lower value of heritability may have a connection with a poor environment. Kang (1994) has stated that quantitative traits are greatly influenced by the environment, which can be seen in this study. According to Noh et al. (2002), moderate heritability value of the traits indicated it had good genetic control, which would be easy for the offspring inbreeding. In comparison to this study, the genetic control was weak and further progeny tests should be carried out in the future.

\section{Conclusion}

The progenies in this study showed variability in the fatty acid composition, iodine value, carotene, height and height increment in oil palm interspecific hybrids. Some of the traits had good values compared to previous studies. High oleic acid is favourable to oil palm breeders. Lower palmitic acid also has its advantages. Low height increment can be introgressed into advanced genetic lines. Progeny MS3452 can be selected as the best performer for oil traits whereas progeny MS3444 can be selected for height increment. Improvement of genetic material in this study can be achieved based on heritability values. Nevertheless, further studies such as progeny testing should be carried out to improve the genetic materials. In addition to that vegetative measurements can also be considered.

\section{Conflict of interest}

The authors declare no conflict of interest.

\section{Acknowledgements}

The work was partly supported by the Ministry of Education Malaysia through the research grant
FRGS/1/2013/STWN03/UITM/02/3. The authors wish to thank Universiti Teknologi MARA (UiTM) and the Malaysian Palm Oil Board (MPOB) for the financial support facilities and experimental materials for this research.

\section{References}

Astorkia, M., Hernández, M., Bocs, S., Ponce, K., León, O., Morales, S., Quezada, N., Orellana, F., Wendra, F., Sembiring, Z., Asmono, D. and Ritter, E. (2019). Analysis of the allelic variation in the Shell gene homolog of E. oleifera and design of species specific Shell primers. Euphytica, 216, 5. https:// doi.org/10.1007/s10681-019-2538-7.

Barba, J., Baquero, Y., Mendoza, L. and Vallejo, G.O.F. (2015). Establishment of inter specific hybrids in ecuador, genetic diversity and sustainability of oil palm in America, presented at International Plam Oil Congress and Exhibition. Kuala Lumpur, Malaysia.

Barcelos, E., Rios, S., Cunha, R.N., Lopes, R., Motoike, S.Y., Babiychuk, E., Skirycz, A. and Kushnir, S. (2015). Oil palm natural diversity and the potential for yield improvement. Frontiers in Plant Science, 6, 190. https://doi.org/10.3389/fpls.2015.00190.

Beirnaert, A.D.F. and Vanderweyen, R. (1941). Contribution à l'étude genetique et biometrique des variétés d'Elaeis Guineensis Jacquin. Nairobi, Kenya: East African Standard. [In French].

Benítez, É. and García, C. (2014). The History of research on oil palm bud rot (Elaeis guineensis Jacq.) in Colombia. Agronomia Colombiana, 32(3), 390-398.

https://doi.org/10.15446/ agron.colomb.v32n3.46240.

Breure, C.J. and Powell, M.S. (1988). The one-shot method of establishing growth parameters in oil palm. IPMKSM. In Proceedings of the 1987 International Oil Palm/Palm Oil Conferences Progress and Prospects 23-26 June 1987, p. 203-209. Kuala Lumpur, Malaysia 
Chaves, G., Ligarreto-Moreno, G.A. and Cayon-Salinas, D.G. (2018). Physicochemical characterization of bunches from American oil palm (Elaeis oleifera H.B.K cortes ) and their hybrids with African oil palm (Elaeis guineensis Jacq.). Acta Agronomica, 67 (1), 168-176. $\quad$ https://doi.org/https:// doi.org/10.15446/acag.v67n1.62028.

Choo, Y.M., Ma, A.N. and Yap, S.C. (1997). Carotenes, vitamin $\mathrm{E}$ and sterols in oil from Elaeis guinenesis, Elaeis oleifera and their hybrids. Palm Oil Development, 27, 1-9.

Kang, M.S. (1994). Applied Quatitative Genetics. 1st ed. USA: The Author.

Kyriakidis, N.B. and Katsiloulis, T. (2000). Calculation of iodine value from measurements of fatty acid methyl esters of some oils: comparison with the relevant American oil chemist's society method. Journal of the American Oil Chemists' Society, 77 (12), 1235-1236. https://doi.org/10.1007/s11746-000 -0193-3.

Mancini, A., Imperlini, E., Nigro, E., Montagnese, C., Daniele, A., Orrù, S. and Buono, P. (2015). Biological and nutritional properties of palm oil and palmitic acid: Effects on health. Molecules, 20(9), 17339-17361.

https://doi.org/10.3390/ molecules200917339.

Montoya, C., Cochard, B., Flori, A., Cros, D., Lopes, R., Cuellar, T., Espeout, S., Syaputra, I., Villeneuve, P., Pina, M., Ritter, E., Leroy, T. and Billotte, N. (2014). Genetic architecture of palm oil fatty acid composition in cultivated oil palm (Elaeis guineensis jacq ) compared's to its wild relative $E$. oleifera (H.B.K) cortes. PLOS ONE, 9(5), 1-13. https:// doi.org/10.1371/journal.pone.0095412.

Noh, A., Mohd Din, A., Marhalil, M., Rajanaidu, N. and Kushairi, A. (2012). Performance of some Elaeis oleifera, interspecific hybrids and backcrosses, presented at International Seminar On Breeding For Sustainability In Oil Palm, p. 1-19. Retrieved on December 2019 from MPOB website: http:// isopb.mpob.gov.my/pdfFile/6th/P9-\%20NOH.pdf

Noh, A., Rajanaidu, N., Kushairi, A., Rafii, Y.M., Din, A.M., Isa, M.Z.A. and Saleh, G. (2002). Variability in fatty acid composition, iodine value and carotene content in the mpob oil palm germplasm collection from Angola. Journal of Oil Palm Research, 14(2), $18-23$.

Rafii, M.Y., Rajanaidu, N., Jalani, B.S. and Kushairi, A. (2001). Genotype x environment interaction and stability analyses in 40 oil palm (Elaeis guineensis Jacq.) progenies over six locations. Journal of Oil Palm Research, 13(1), 11-41.
Rafii, M.Y., Rajanaidu, N., Jalani, B.S. and Kushairi, A. (2002). Performance and heritability estimations on oil palm progenies tested in different environments. Journal of Oil Palm Research, 14(1), 15-24.

Rajanaidu, N., Ainul, M.M., Kushairi, A. and Mohd Din, A. (2013). Historical review of oil palm breeding for the past 50 years - Malaysian journey. In Proceeding of the International Seminar on Oil Palm Breeding Yesterday, Today and Tomorrow, p. 11-28. Kuala Lumpur, Malaysia.

Sunilkumar, K., Mathur, R.K., Sparjanbabu, D.S. and Pillai, R.S.N. (2015). Evaluation of interspecific oil palm hybrids for dwarfness. Journal of Plantation Crops, 43(1), 29-34.

Yaakub, Z., Kamaruddin, K., Singh, R., Mustafa, S., Marjuni, M., Ting, M.N., Amiruddin, M.D., Leslie, L.E.T., Ooi L.C.L., Sritharan, S., Rajanaidu N., Jansen, J. and Abdullah, M.O. (2020). An integrated linkage map of interspecific backcross $2\left(\mathrm{BC}_{2}\right)$ populations reveals QTLs associated with fatty acid composition and vegetative parameters influencing compactness in oil palm. BMC Plant Biology, 20, 356. https://doi.org/10.1186/s12870-020-02563-5.

Yap. S.C., Choo, Y.M., Ooi, C.K., Ong, A.S.H. and Goh, S.H. (1991). Quantitative analysis of carotenes in the oil from different palm species. Journal of Oil Palm Research, 3(2), 369-378.

Yee, J.T.C. and Chandran, M.R. (2005). A century of oil palms in Malaysia. International News on Fats, Oils and Related Materials, 16(3), 142. 